\title{
Tješiteljska uloga filozofije — filozofsko savjetovanje u službi radnika
}

\author{
Ana Jeličić*, Antun Japundžić**
}

\begin{abstract}
Sažetak
Najteži problem današnjice mnogi vide u nezaposlenosti. Taj težak problem baca u sjenu stanje prezaposlenog čovjeka. Prezauzetost stoji naspram nedostatka okupacije i izaziva veliko nezadovoljstvo, strah, umor, osjećaje besmisla i bezizlaznosti. U nemogućnosti da sam odlučuje što će okupirati njegov život i vrijeme čovjek ima osjećaj da ih gubi, da mu oni izmiču, kao i identitet koji poistovjećuje s radnim sposobnostima. U svijetu je posljednjih godina zabilježen trend po kojem je čovjek na radnom mjestu radnik, a u slobodno vrijeme postaje filozofom dok je filozof tijekom tjedna prezaposleni radnik, a vikendom težak. Drugim riječima, filozofi napuštaju ekskluzivnost $i$ akademske krugove da bi rješavali probleme svakodnevnice. Može li filozofija poslužiti kao terapija (L. Marinoff, G. Reale ili Seneka), kao utjeha i tješitelj (A. de Botton), savjetnik i mogućnost novog života (G. B. Achenbach), radniku željnom odmora, dokolice, kreativnosti, kontemplacije i opuštenosti ( J. Pieper) učeći ga postavljati pitanja o vlastitom životu $i$ čineći ga protagonistom tog života? Ili aplicirana filozofija postaje još jedna tržišna priča?

Ključne riječi: rad, radnik, prezaposlenost, dokolica, filozofija, filozofsko savjetovanje
\end{abstract}

\section{Uvod}

U ovom radu postavlja se pitanje može li danas filozofija biti novo/staro mjesto mogućeg herojskog otpora nihilizmu suvremenog načina života, kao nov/stari način suočavanja s ljudskim patnjama i mjesto otkrivanja izgubljenih vrijednosti? Pokušati će istražiti mogućnost filozofije da odgovori na potrebe suvremenog čovjeka, prvenstvo njegove brige koje uzrokuje nezaposlenost, u jednakoj mjeri kao i prezaposlenost koja ne ostavlja čovjeku puno slobodnog vremena. U tom smislu ne činimo ništa novo. Na globalnoj razini to je već učinio UNESCO.

* Dr. sc. Ana Jeličić, Sveučilišni odjel za forenzične znanosti, Sveučilište u Splitu. Znanstveni centar izvrsnosti za integrativnu bioetiku, Sveučilište u Zagrebu. E-pošta: anjelici08@gmail.com

** Dr. sc. Antun Japundžić, Katolički bogoslovni fakultet u Đakovu. Sveučilište Josipa Jurja Strossmayera u Osijeku, Hrvatska. E-pošta: antun.japundzic@gmail.com 
Govoreći o filozofiji u širem smislu riječi, UNESCO Strategy on Philosophy (2004.) ističe nekoliko najvažnijih aktualnih termina u filozofiji danas. To su ekologija, pravednost, sloboda, demokracija, bioetika, siromaštvo, mir, dostojanstvo, odgovornost, jednakost i identitet. Tražeći nove strategije za razvoj filozofije, poziva vlade raznih zemalja da podrže one znanosti koje razvijaju slobodno mišljenje i kritičke vještine. U tome prednjači filozofija kojoj se tim dokumentom priznaje njezina sposobnost da se suočava, ne samo s apstraktnim, intelektualnim, složenim fenomenima i problemima na katedrama pojedinih fakulteta, nego is osobnim i svakodnevnim ljudskim brigama. Tomu je pridonijela popularizacija filozofije kod javnosti posljednjih godina i buđenje svijesti o važnosti filozofske analize s ciljem da se inspirira za akciju, traženje i rješavanje gorućih problema, ali i da se nadiđe filozofska getoizacija. ${ }^{1}$

Osim tog pokušaja oživljavanja filozofije u korist konkretnog života novijeg datuma, važno je imati na umu da su se ljudi u antici bavili filozofijom da bi naučili dobro i lijepo živjeti, da bi postigli blaženstvo. Filozofijom se usvajalo uvjerenje da se sreća može postići, da je uvjetuju sloboda, što manje potreba i sposobnost gospodarenja samim sobom. Antički je filozof bio sklon razgovoru, dijalogu, diskusiji, težio je istini, spoznaji, bio je sposoban oduprijeti se nametnutomu, krasio ga je nemirni duh, onaj u potrazi. Bio je kritičan, neposlušan, nemiran i hrabar, odnosno, sve ono što moderni čovjek teško ostvaruje. Stoga on u novije vrijeme pomoć traži u filozofiji u kojoj prepoznaje moćnog prijatelja u suočavanju s problemima svakodnevnice.

\section{Novi društveni koncepti}

Suvremenog čovjeka iznevjerila su materijalna i znanstveno-tehnološka obećanja iz minula dva desetljeća, te su se u novije vrijeme u centar promišljanja vratile temeljne vrijednosti poput života, ljubavi, mira i slobode. Pomak u svijesti dogodio se, međutim, već 60-ih godina 20. stoljeća, a očitovao se kao traganje za samoispunjenjem koje je započela skupina mladih ljudi iz SAD-a. Daniel Yankelovich u svojoj knjizi Nova pravila: Traganje za samoispunjenjem u svijetu izokrenutih vrijednosti ${ }^{2}$ donio je priču iz 70-ih godina u kojoj je poznata tvrtka General Motors objavila natječaj za manje plaćene, na koje se javilo oko dvije tisuće visokoobrazovanih ljudi. Autor je to silaženje s viših na niže platne liste in-

1 Ljudi se naime u svom poslu i svakodnevnom životu suočavaju sa sve težim životnim izborima i većim brojem mogućnosti. Raste kompetitivnost na tržištu rada, a s time brige i stres koji se manifestiraju na razne načine. U jednakoj mjeri, lako se gubi posao, a s time i želja za planiranjem budućnosti, kao i osjećaj za smisao obavljanja nekog posla. U tom kontekstu i u takvim životnim uvjetima postavlja se pitanje može li filozofija pružiti čovjeku pomoć, može li ga utješiti, umiriti, okupirati čovjekove misli pozitivnim idejama, pružiti neku vrstu utočišta.

2 Usp. Daniel Yankelovich, Nova pravila: Traganje za samoispunjenjem u svijetu izokrenutih vrijednosti, Zagreb, 1994, str. 9-52. Sociolog Daniel Yankelovich pratio je kulturološke, ali i društvene i obiteljske promjene u američkom društvu 70-ih godina 20. stoljeća, što je rezultiralo spomenutom knjigom. 
terpretirao kao prvi korak prema kojemu se težilo tih godina, što je bilo u skladu s trendom porasta brige o samom sebi. Tomu je, prema Yankelovichu, prethodio nemir koji se očitovao razdražljivošću, uznemirenošću, neuravnoteženošću, osjećajem besmisla, monotonosti i općim nezadovoljstvom u društvu. ${ }^{3}$ Spomenuti sociolog potražio je i uzroke takvog pojedinačnog i kolektivnog stanja te zaključio da ih je teško detektirati. Uzroci su mogli biti razni, od sekularnog humanizma, društveno-političkog pluralizma, veće slobode izbora i izražavanja, što je omogućilo izlazak iz kolotečine i obećavalo promjene, pa sve do novih mogućnosti istraživanja vlastitih potencijala i do tada nezamislive mogućnosti napuštanja obiteljskog posla i tradicije $\mathrm{s}$ ciljem ispitivanja vlastitih talenata $\mathrm{i}$ vještina. Promjene je autor najprije uočio u obiteljima i brakovima te potom i u profesionalnom svijetu, a prethodila su im nova poimanja osobe, sreće, zdravlja, uspjeha, rada, ali i odmora.

Čitajući djelo na koje se referiramo iz današnje perspektive, čini se da se američki san tih godina pokazao samo snom koji se raspršio u kapitalističkoj stvarnosti u kojoj se čovjek egocentrično usmjerio samo na sebe, na svoja prava, želje i na krivo shvaćenu slobodu. Pokazuje se da je čovjek svoj identitet dugo gradio na temelju koncepta uspjeha što je čovjeka-radnika, naposljetku, dovelo do individualističkog bunta 70 -ih godina, ali i do preispitivanja samog koncepta uspjeha.

Nekoć je biti uspješan značilo: biti dobar roditelj, imati novca te steći položaj i ugled u društvu. Situacija se, međutim, s godinama mijenjala. Dobro plaćeni posao izgubio je prednost pred poslom koji čovjeka čini sretnim i zadovoljnim, a ugled više nije ovisio o poslu kojeg netko obavlja. Biti uspješan, na prvom mjestu, znači biti slobodan od poslovnih okova i brojnih obveza, što su ujedno i uvjeti sreće koja se oduvijek usko veže uz koncept uspjeha. Sreća se dugo vremena vezala uz materijalno blagostanje, sigurnost i zbrinutost obitelji u financijskom smislu. Slabije ekonomsko stanje i gospodarska kriza nagnale su čovjeka da sreću potraži u slobodnom vremenu, u relaksaciji, u pustolovinama, spontanosti, umjetnosti, ili rukotvorinama. $\mathrm{Na}$ istim mjestima, pokušao je čovjek izgraditi i novi koncept dobrog života, te je sebi postavio niz pitanja: Za što vrijedi živjeti? Za što se vrijedi žrtvovati? Zašto činim ono što činim? Je li time moj život bolji, plemenitiji, vrjedniji? Takva i slična pitanja otvorila su pogled na život i njegov smisao, što je urodilo težnjom za puninom života »koji bubri od slobodnog vremena, novih iskustava i uživanja kao nadomjeska za uredan i na posao usredotočen život ranijih desetljeća.$^{4} \mathrm{U}$ prvi plan tako izlaze: kreativnost, razonoda, autonomija, zabava, jednostavne stvari, nova životna energija ili običan joy de vivre.

3 U filozofskom ozračju to društveno, ali i osobno stanje pojedinaca zabilježio je egzistencijalizam, filozofski pravac koji se osim na filozofskim katedrama prenosio kroz romane koje se usudimo pojmiti kao nove oblike popularizacije filozofije, primjerice J. P. Sartre u Mučnini i A. Camus u Strancu govore o apsurdnosti ljudske situacije, a život se interpretira kao ozračje straha, tjeskobe, mučnine.

4 Daniel Yankelovich, Nova pravila, str. 21. 


\subsection{Koncept rada}

Sve navedene promjene, kako u svijesti pojedinaca tako i na društvenoj razini, imale su utjecaja na poimanje rada. U antičkom svijetu rad je bio shvaćen kao zla sudbina. U robovlasničkom društvu aristokracija se bavila samo onim što im je donosilo užitak i razonodu. Tako aristokracija nije radila, dok su robovi obavljali za njih težačke poslove. Buržoazija je u 18. stoljeću počela cijeniti rad, odnosno odgovornost, kreativnost i inicijative koje rad neminovno uključuje. Rad je postao temeljna vrijednost, a slobodno vrijeme postalo je vrijeme za rekreaciju i obnovu snage za rad. U 19. stoljeću došlo je do trenda napuštanja agrikulturnih poslova u korist onih koji se obavljaju u zatvorenim prostorima. Ti poslovi, tvornički pa uredski, ubrzo su radnicima postali repetitivni i monotoni, zbog čega su dobili dojam da se ponavljaju, te da nemaju niti početak niti kraj. Osim toga, posao je nekoć bio vezan uz prirodne cikluse, a radnici su mogli vidjeti i uživati plodove svog rada i svojih ruku, to jest mogli su pratiti napredak i pomak u radu koji su započinjali, ali i završavali. Plodovi rada u uredskim poslovima radniku su uglavnom nevidljivi. Rad se tako odijelio od rezultata rada. Na svojem radnom mjestu čovjek je dobio dojam automatizma, beskrajnog ponavljanja, što uzrokuje osjećaj besmisla i obavljanja »Sizifovog posla«. Osim toga, načelo upravljanja radom postalo je iskoristivost i učinkovitost, a radnik je postao dužnosnik. Svoje nezadovoljstvo radnik je tako sve više pokazivao, ne samo kroz štrajk nego i kroz osobnu tugu, povlačenje u sebe, frustracije, nervozu što se stručno definiralo tek u novije vrijeme kao poslovno sagorijevanje. ${ }^{5}$

Usporedo s takvim stanjem na području rada, mijenjalo se i poimanje slobodnog vremena u kojem je čovjek slobodan od rada u percepciju slobodnog vremena kao vremenu za nešto. U tom smislu, postao je privilegiran svatko tko ima vremena na raspolaganju, odnosno u mogućnosti je vrijeme ispuniti nečim društveno beskorisnim, ali osobno veoma važnim. ${ }^{6}$

U svijetu kapitalističkog duha, pak, rad i slobodno vrijeme uskoro su postali potrošački obilježeni. Tako se i slobodno vrijeme počelo trošiti na kupovanje i gomilanje nepotrebnih materijalnih dobra, a svijetom rada dominiraju kalkulabilnost i učinkovitost. ${ }^{7}$

Istovremeno s ekonomijom zarade i potrošnje mijenjala se i kultura, što je vršilo određeni utjecaj na čovjekovu psihu. Industrijska, masovna proizvodnja stvarala je uvijek nove proizvode koje su mnogima ostale neispunjene želje, a time se rađalo sve veće nezadovoljstvo i frustracije. Između ostalog, uvjerenje da se samoostvarenje može postići stječući i gomilajući materijalna dobra odvelo je

5 O poslovnom sagorijevanju (eng. burn out sindrom) vidi više u: Maja Jakšić, Sindrom izgaranja na radnome mjestu. Burn out sindrom, Đakovo, 2014, str. 49-155.

6 Usp. Fernando Savater, I dieci comandamenti nel XXI secolo, Milano, 2005, str. 39-53.

7 Ranije u povijesti situacija je bila suprotna: Ne-rad bio je simbol dobrostojećeg društvenog položaja, a dokolica je bila zapravo ne-rad. Ekonomist i sociolog Veblen govori o dokoličarskoj klasi koja se bavila stvarima i poslovima koje nisu ni produktivne ni korisne. Usp. Thorstein Veblen, The theory of the leisure class, URL: http://www.gutenberg.org/files/833/833-h/833-h. htm\#link2HCH0003 (preuzeto 11.rujna 2013.). 
radnike u osjećaj nepremostive unutarnje praznine. Do nedavno je radnik smisao rada nalazio barem u novcu kojeg je zarađivao i trošio, te u slobodnom vremenu, a zatim je ekonomska i gospodarska kriza uništila i to zadovoljstvo. Radnik se počeo osjećati zakinutim i otuđenim, što je bilo adekvatno stanju čovjeka uopće. ${ }^{8}$ Novi uvidi u stvarnost, a potom i spomenute promjene, zahtijevali su nova filozofska pitanja, ali i dokolicu.

\subsection{Koncept odmora i lijenosti}

Kako se kroz povijest mijenjao koncept rada, tako se mijenjao i koncept odmora. Prvotno je odmor značio predah od fizičkog rada koji je donosio konkretne plodove. Od kada se radom počeo stjecati isključivo novac, odmor je postalo vrijeme potrošnje, period konzumacije. To je odvelo do toga da je čovjek svoje slobodno vrijeme počeo koristiti za razne aktivnosti, kao priliku za novo iskustvo, za igru, pustolovinu ili avanturu. Odlazi na odmor imajući do u tančine razrađen plan odmora. Taj plan i takav odmor počeo je stvarati čovjeku samo dodatne probleme i opterećenja. Odmor mu je odjednom postao prijetnja i ugroza, počeo je čovjeka umarati više od rada. Išlo se sve do toga da je čovjek počeo tražiti odmor od odmora.

Ukoliko je rad shvaćen kao najveća vrijednost, izostanak rada nešto je negativno što se povezuje uglavnom sa lijenošću. Lijenost se, naime, i prije modernog doba moralno osuđivalo gotovo u svim društvima, kulturama i religijama. Lijenost je percipirana kao grijeh, porok, nepokretnost, pasivnost, nedostatak aktivnosti i motiviranosti za rad, paraliziranost duha, nedostatak interesa i unutarnja praznina. Kierkegaard ju je vidio kao sestru praznini, kao nedostatak želja i strasti, zaglavljenost u trenutku ili u nekoj situaciji. ${ }^{9}$

Razvojem psihologije te dubljim uvidima religiozne psihologije i duhovnosti, lijenost se u suvremeno doba počela tretirati kao bolest. Lijenčina nije više tek neradnik, nego je žrtva samog sebe, čovjek pun unutarnjih konflikta, u vječnom bijegu od odgovornosti, od izbora i od mogućnosti da nešto u svojem životu promijeni. Riječ je o duhovnoj lijenosti od koje boluje suvremeni čovjek fiksiran na jednom mjestu. Lijenost, dakle, postaje bolest prezaposlenog čovjeka koji se užasava odmora. ${ }^{10}$ Moderni lijenčina ne nalazi spas na kauču, nego u uredu, u prekovremenom radu i to najčešce u mehaniziranom, robotiziranom i rutinskom radu. Natrpani radni ritam čovjeku ne ostavlja nimalo vremena za distanciranost, za mir, tišinu, razmišljanje, motrenje, osluškivanje, sanjarenje, molitvu ili neke

8 Usp. Hrvoje Jurić, 11 teza o slobodnom vremenu i radu, Zarez, 11/266 (2009), str. 34-35.

9 Usp. Giovanni Cucci, Il fascino del male. I vizi capitali, Rim, 2008, str. 313-359.

10 Ugledni talijanski psihoanalitičar Umberto Galimberti lijenost ne zove ni grijehom ni bolešću. Za njega je lijenost praznina, nihilizam, egoizam koji pripisuje uglavnom mladim ljudima. Suvremena lijenost očituje se kao uspavanost, zatvorenost u svoj svijet, najčešće virtualni, svijet pun odustajanja, smatra Galimberti. Iako je ona pomanjkanje volje za životom i nedostatak životne energije, nerijetko se živi u sredinama koje čine dio enormne zabavljačke industrije i zahtijevaju velike količine energije. Usp. Umberto Galimberi, Vizi capitali e nuovi vizi, Milano, 2007, str. 23-31. 
druge duhovno-psihičke potrebe. Stoga suvremeni hiperradnik zapravo izbjegava dokolicu koja omogućuje čovjeku da (p)ostane čovjek, da bude ono što je pozvan biti. ${ }^{11}$

Tako dolazimo do novog poimanja odmora. Ono nije više ni konzumeristički ispušni ventil niti je lijenost. Prezaposleni čovjek uvidio je da vlastito očovječenje ne može ostvariti kroz rad i posao, nego upravo suprotno, u dokolici. ${ }^{12}$ Odmor se očituje kao spas za čovječnost i dostojanstvo čovjeka, jer pravim odmorom se »oslobađa prostor za život i onoj drugoj dimenziji čovjeka, koji nadilazi interes i korisnost. U vrijeme odmora čovjek može biti na drugi način, osoba onkraj svih uvjetovanosti i interesa. Može biti ne samo čovjek radnik već i čovjek igre, stvaratelj, čije se stvarateljstvo ne ograničava isključivo na posao «.13

\subsection{Novo poimanje slobodnog vremena $i$ dokolice}

Dokolica kao vrijeme za može se bolje razumjeti ukoliko se vrijeme poistovjeti sa životom. Vrijeme i život gotovo su sinonimi. Da bi čovjek otkrio vrijednost vremena koje ima na raspolaganju, odnosno vrijednost života koji živi, potrebno je da shvati smisao svojih aktivnosti i svojeg rada, odnosno da uvidi smisao (ili besmisao) svojih djelatnosti koje mu ispunjavaju vrijeme, odnosno život. ${ }^{14}$ Vrijeme je zapravo život koji čovjek ima i kojeg živi, a slobodno vrijeme nije tek vrijeme slobodno od rada, nego vrijeme $z a$ razmišljanje, preispitivanje, otkrivanje onog što život pruža.

U tom smislu, razmišljanje i propitkivanje o ključnim životnim pitanjima lakše je ostvariti u slobodnom vremenu, rasterećenom od posla i svakodnevnih briga, odnosno tada kada se postigne dokolica kao posebno stanje uma koje podrazumijeva odušak i odmak od rada i posla. I njemački filozof Pieper u spomenutom djelu jasno izlaže svoje shvaćanje dokolice kao prostora koje odgovora na pitanja o smislu života i rada, vrijednostima, cilju ljudskog života. Čovjek je pozvan da kroz nju oblikuje svoju osobnost kao što je donedavno to činio poslom kojeg je obavljao.

Dokolica, dakle, nije besposličarenje, ljenčarenje, predah od dnevnih ili tjednih radnih obaveza, nego slobodno vrijeme za osobni rast, ostvarenje, za istraživanje svoje kreativnosti, duhovnosti, slobode, potencijala, dostojanstva i smisla. To je vrijeme za gledanje, opažanje i spoznavanje, refleksiju i povlačenje u sebe kako bi se razumjelo što se događa ili kamo se ide. Dokolica je prilika da

11 Usp. Josef Pieper, Pohvala dokolici. Oslobodite se kulta rada i pronadite istinski smisao života, Split, 2011, str. 59-68.

12 Pojam dokolice proizlazi iz značenja latinske riječi otium, »slobodno vrijeme«. Hrvatski enciklopedijski rječnik (2002.) i Rječnik hrvatskoga jezika (2000.) dokolicu poistovjećuju sa »slobodnim vremenom « u kojem se ipak nešto osmišljeno radi. Usp. Vladimir Anić i sur., Hrvatski enciklopedijski rječnik, Zagreb, 2002, s. v. dokolica; Rječnik hrvatskoga jezika (ur. Jure Šonje), Zagreb, 2000, s. v. dokolica.

13 Nedjelja radi čovjeka, Zagreb, 2004, str. 11.

14 Usp. Giovanni Reale, La filosofia di Seneca come terapia dei mali dell'anima, Milano, 2008, str. $25-35$. 
se čovjek susretne sa samim sobom. Ona je trenutak stvaralačkog mira koji se poistovjećuje sa slavljem, počinkom, ali i životom u punini. Istovremeno, ona je stanje duše, unutarnja nezaposlenost, šutnja, osluškivanje, spokojno prihvaćanje, prepuštanje tijeka stvari i događaja, ne da bi čovjek imao, nego da bi bio. Ona je okrepljenje kao u dubokom snu, slaganje stvari, doživljaja i osjećaja. Živi od prihvaćanja i otvorenosti svijetu, a moguća je »tamo gdje je čovjek jedno sa samim sobom, gdje on prihvaća svoj vlastiti bitak « ${ }^{15} \mathrm{u}$ svim njegovim dimenzijama.

\section{Dokolica kao vrijeme za filozofiju}

Čovjek suvremenog doba pritisnut brojnim poslovima, vlastitim neostvarenim željama, nedovršenim projektima i neizdrživim unutarnjim i vanjskim pritiscima pomoć je potražio kod svojeg bližnjeg, u nadi da egzistenciju može rasvijetliti u dijalogu i susretu s drugim ljudima. ${ }^{16}$ Tema dijaloga je osobni život i nove postmaterijalističke vrijednosti koje zahtijevaju nove oblike komunikacije, umnosti i znanja. Riječ je o znanju koje se razvija kroz plemenitost, razboritost i iskustvo, a odgovara recta ratio. ${ }^{17}$ Instrumentalni um i tehnološko-znanstveno znanje koji su obilježili tehničko-ekonomsku globalizaciju, pali su u drugi plan u korist mnogovrsnosti znanja i njegovoj raznolikosti. Sve više se cijeni znanje koje služi životu i čovjeku koji je njegov svjesni protagonist, subjekt u potrazi za dobrim životom i puninom života. Pomak u svijesti dogodio se 80 -ih godina 20. stoljeća, kada je čovjek shvatio da dobar život i odgovor na temeljna ljudska pitanja nije u sferama pragmatizma, materijalizma, tehnicizma, racionalizma, globalizma, egzistencijalizma, a ni psihologizma. ${ }^{18}$

Tada se, naime, filozofija iznova pokazala kao znanje, otvoren pogled, mudrost, ali i aktivnost, proces, promišljanje koje podrazumijeva slušanje, razumijevanje, argumentiranje, kao i mjesto koje daje novi okvir unutar kojeg se razmatraju pitanja, koncepti i problemi, i to zahvaljujući angažmanu pojedinih filozofa. ${ }^{19} \mathrm{U}$ tom desetljeću filozofija se počinje prakticirati kao znanost u službi radnika. Taj svoj potencijal ostvaruje ukoliko pomaže čovjeku da se prestane poistovjećivati s poslom koji obavlja, uči ga da ne robuje isključivo zahtjevima posla (tržišta) i da se ponovno dade $u$ potragu za istinom, cjelinom i smislom. Filozofija pomaže preopterećenomu radniku već onda kada ga uspijeva naučiti postavljati prava pitanja: Što je važno u životu? Koje su vrijednosti najvažnije? Kakav je i što je to dobar život? Gdje tražiti svoju sreću? Kako otkriti skrivene sposobnosti i talente, postići svrhu i otkriti smisao svog života? Kako u svemu tome ostati čovjekom?

15 Josef Pieper, Pohvala dokolici, str. 62.

16 Usp. Ante Kusić, Dva aspekta suvremenog egzistencijalizma. Kako Jean-Paul Sartre i Gabriel Marcel gledaju na temeljne probleme ljudske egzistencije, Crkva u svijetu, 1976, 11, str. 123-131.

17 Usp. Ante Pažanin, Suvremena globalizacija i vlastitost praktične filozofije, Politička misao, 1999, 36, str. 9-25.

18 Usp. Ante Pažanin, Suvremena globalizacija i vlastitost praktične filozofije, str. 9-25.

19 Usp. Peter J. King, Philosophy against manipulation, The UNESCO Courier, 2007, 9, str. 10-11. 
Na osobnom planu ta potraga započinje u trenutku najvećeg umora, onog koji stoji na kraju jednog života koji se živi po automatizmu, u trenutku kronične iscrpljenosti i konačnog pada. ${ }^{20}$ Polazi se od zasićenosti iz koje jednog dana izranja jedno od najtežih pitanja: zašto uopće radim? Već to pitanje ukazuje na buđenje svijesti, na potencijalne promjene i na mogući izlazak iz nezadovoljavajuće ili zabrinjavajuće situacije. U tim prilikama rastvara se plodno tlo za prakticiranje filozofije koja bi bila od koristi čovjeku u njegovoj konkretnoj životnoj situaciji.

\section{Popularizacija filozofije}

Neosporno je da su suvremeni filozofi, koji su se usudili sići sa sveučilišne katedre ponovno na trg (pa i u virtualni forum), ponudivši filozofsku misao i približivši je nefilozofima da im bude na korist, često nailazili i nailaze na brojne kritike. Svjedoci smo kako se filozofe koji prakticiraju filozofije pred nekritičkom masom na javnom mjestu često optužuje za slatkorječivost, dodvoravanje, psihologiziranje, medikaliziranje filozofije i senzacionaliziranje filozofskih tema preko medija, foruma, brojnih publikacija, websiteova, blogova, filmova i nezaobilaznih novinskih rubrika.

Metode populariziranja filozofije su brojne. One najučestalije u svijetu su: philosophical narrative practice, odnosno filozofska praksa koja promovira narativni koncept znanja, ali i filozofiju kao narativnu terapiju (filozofski storytelling kao terapijska metoda); potom café philosophique ili običaj koji je zaživio u Francuskoj 90-ih godina da se u filozofskoj kavani sastaju filozofi i građani koji kroz dijalog i rasprave obrađuju neku temu; i na koncu sve popularniji oblik savjetovanja, philosophical counseling ili filozofsko savjetovanje. Te filozofske prakse imaju zadatak da pokušaju pomoći čovjeku u svladavanju najbolnijih životnih problema (primjerice gubitka voljene osobe), u uređivanju narušenih međuljudskih odnosa, u nošenju s posljedicama prirodnih katastrofa, prihvaćanju bolesti, ali i suočavanju s izvorima svojeg umora ili stresa, koji podrazumijevaju, u velikoj mjeri, neuredan radni ritam i prekomjerne obveze.

\subsection{Filozofsko savjetovanje}

Filozofsko savjetovanje novi je način prakticiranja filozofije koji je započeo Gerd Achenbach u Njemačkoj 80-ih godina 20. stoljeća, te se brzo proširio Sje-

20 Raffaella Soldani u predgovoru knjige Gerd B. Achenbacha La consulenza filosofica. La filosofia come opportunità di vita (Milano, 2009, str. 9-17), referirajući se na W. Schmida, govori o potrebi za filozofijom koja uvijek postoji, ali intenzitet te potrebe varira kroz različita povijesna razdoblja. On je jači što je osjećaj besmisla veći, ritam života brži, a način života u potpunosti depersonaliziran i automatiziran. Stoga je bilo za očekivati da se u hipertehniciziranom društvu javi individualna potreba za filozofskom mišlju, filozofskim tekstovima, profesorima filozofije i filozofima, kao mogućim savjetnicima u vođenju života u kojem pojedinac gubi svoj integritet, osobnost, identitet i dostojanstvo. 
vernom Amerikom, a zatim i Europom. ${ }^{21}$ Praksa se ne razlikuje bitno od prakticiranja filozofije u antici, kada su filozofi po trgovima savjetovali sugrađane kako dobro živjeti i kritički razmišljati, vjerujući, poput Epikura, da je prazan svaki filozofski argument koji ne pomaže riješiti ili ublažiti ljudsku patnju. Ono specifično filozofsko u pristupu ljudskoj patnji je uvjerenje da se svakomu problemu treba pristupiti postavljanjem ispravnih pitanja. Zato ta filozofska praksa želi podučiti ljude kako se suočiti s pitanjima i problemima na argumentiran i kritički način. Tada filozofska praksa postaje umjetnošću vođenja dijaloga i izmjene ideja, ali i jednom vrstom terapije koja je alternativa psihoterapiji. ${ }^{22}$ Ona je naime terapija za zdrave, kako ju je nazvao filozofski savjetnik Pater March, ali nezadovoljne ljude. Riječ je o ljudima koji su zarobljeni u dnevne rutine i koji ne vide smisao svojeg života, o ljudima koje muči osjećaj unutarnje praznine i koji su uvjereni da njihov život ne odgovara njihovim sposobnostima. Ti isti žele pronaći smisao, izgraditi svoju osobnost, upoznati sami sebe, izići iz zatvorenog kruga kuća-posao-kuća, doći do unutarnjeg mira, shvatiti i biti shvaćeni. Žele iskopati unutarnje motive svojih postupaka i svojega rada, a ne samo odgovarati na vanjske poticaje. »Ono što ih pokreće nije nikada Kantovo pitanje ‘što moram raditi?' već Montaignovo pitanje 'što radim?' «. ${ }^{23}$ Filozofsko savjetovanje odvija se na individualnoj razini, u grupama (filozofski caffé) ili organizacijama, i to na različite načine: dijalogizira se na neku opću temu bez posebnog filozofskog uporišta, povezuje se neki problem ili argument uz ime nekog filozofa, njegovu filozofiju odnosno njegove tekstove. Postoje i stupnjevi istraživanja, tj. rješavanja problema: od najniže razine definiranja i priznavanja problema, preko otkrivanja osjećaja koje ono izaziva, analize potencijalnih stavova koji se mogu zauzeti u odnosu na problem, sve do kontemplacije, odnosno razine na kojoj se postiže unutarnja ravnoteža i mir. Savjetovanje je postiglo ispravan učinak ukoliko je čovjek uočio i iznio svoj problem, odlučio ga riješiti te je pomoć i rješenje pronašao u filozofiji. Prvi korak je prastari filozofski zadatak koji se postavlja pred čovjeka: da upozna samog sebe i pronađe pravu mjeru. ${ }^{24}$ Iako se najviše služi upravo dijalogom kao metodom savjetovanja, savjetovanje je otvoreno novim putovima i metodama s obzirom na predmet, problem ili misao kojom se bavi. Međutim, najčešći predmeti dijaloga, između filozofskog savjetnika $\mathrm{i} »$ klijenta« svakodnevni su problemi (smisao, etika, vrijednosti, sreća, zdravlje, uspjeh), odnosno svi oni koncepti koji prolaze transformacije u svijesti suvremenog čovjeka, o kojima je prethodno bilo govora.

21 Već je 1982. godine u Bergisch Gladbachu u Njemačkoj osnovano Društvo za filozofsko savjetovanje koje se ubrzo razvilo u internacionalno društvo. Usp. Gerd B. Achenbach, La consulenza filosofica. La filosofia come opportunità di vita, Milano, 2009, str. 9-34.

22 Dok se psihoterapija osvrće na prošlost s ciljem da uredi međuljudske odnose i izliječi pacijenta, filozofsko savjetovanje okrenuto je budućnosti, kraće traje i cilj mu je pomoći čovjeku da shvati u čemu leži problem, da reflektira o uzroku problema i da popuni unutarnje praznine tražeći smisao svojeg života kroz dijalog s drugim ljudima.

23 Gerd B. Achenbach, La consulenza filosofica, str. 20.

24 Usp. Lou Marinoff, Platone e' meglio del Prozac, Milano, 2002, str. 11-77. 
Filozofija se oduvijek bavi čovjekom i onim što čovjeka čini čovjekom, onim što čovjek treba biti da bi živio u miru sa sobom, drugim ljudima i svijetom. ${ }^{25} \mathrm{KaO}$ znanost koja prati razvoj ljudske svijesti i uvodi red u ljudsko poimanje svijeta, modernomu čovjeku, posebice prezaposlenomu radniku, filozofija se predstavlja kao izazov, odnosno moguće rješenje za njegove probleme. Filozofski savjetni$\mathrm{ci}^{26}$ imaju zato dosta posla upravo s prezaposlenim ljudima, s onima kojima je uskraćen pravi omjer rada i odmora (ili dokolice), kojima poslovni uspjeh gradi identitet, odnosno s onima kojima posao narušava međuljudske odnose i koji su duboko razočarani svojim životom i radom, te imaju dojam da gube vrijeme, odnosno život.

\section{Može li i kako filozofija utješiti prezaposlenog radnika?}

Osim savjetovanja, filozofija ima i važnu tješiteljsku ulogu. Iznimno popularni suvremeni francuski filozof i publicist Alain de Botton svoje brojne čitatelje uvjerava da ih u slučaju prezaposlenosti, kao i nezaposlenosti, upravo filozofija može utješiti. Ukoliko se čovjek osjeća nevidljivim u društvu, ima problema s novcem, muči ga tjeskoba ili bilo koja druga životna poteškoća, de Botton utjehu nalazi u filozofiji. Filozofija može pomoći čovjeku da nauči misliti svojom glavom, da bude krepostan, da nađe pravu mjeru, da otkrije unutarnje konflikte, da bude hrabar, da otkrije što ga čini sretnim ili kako da živi dobar život. ${ }^{27}$ Filozofija istražuje autentične ljudske potrebe, unosi red u misli, ohrabruje na razmišljanje i istraživanje srži problema koji se izvana očituju na različite načine kao bijes, tjeskoba, bol, agresija, nelagoda i slično. »Umjesto Prozaka, Platon «, ${ }^{28}$ sugerira suvremeni filozof Lou Marinoff. Taj filozofski savjetnik sugerira ljudima da ne ubijaju niti uspavljuju pitanja ili istinske potrebe, nego da se s njima suoče, da ih prihvate i da na njih nastoje odgovoriti. Mnogo prije suvremenih filozofa Seneka je bio uvjeren da ga je filozofija držala na životu, jer je disciplina koja pomaže čovjeku da nadvlada sukobe koji nastaju u sudaru vlastitih želja sa stvarnošću. Upozoravao je da se najteže nosimo s onim problemima koje nismo sposobni analizirati ili racionalizirati. Neriješeni problemi, kao i oni kojima pojedinac ne vidi uzrok, vode $\mathrm{k}$ frustracijama i k bijesu pa on poziva na svakodnevnu refleksiju o vlastitom životu, ali i o mogućim događajima, kako bi se čovjek za njih što bo-

25 Usp. Nicolo Abbagnano, La saggezza della vita. Ogni giorno la ricerca della felicità, Milano, 1985, str. 5.

26 Među najpoznatije svjetske filozofske savjetnike i utemeljitelje filozofskog savjetovanja spadaju: Gerd B. Achenbach, Ran Lahav, Lou Marinoff i Marc Sautet.

27 Usp. Alain de Botton, Le consolazioni della filosofia, Parma, 2000, str. 67-96.

28 Riječ je o djelu Lou Marinoffa Plato, Not Prozac! Applying Eternal Wisdom to Everyday Problems, koje je privuklo veliki broj čitatelja i steklo planetarnu popularnost. Autor obrazlaže utjecaj i mogućnosti filozofije odnosno filozofskog savjetovanja kao metode koje mogu pomoći čovjeku da se nosi sa svakodnevnim frustracijama, strahovima, nedoumicama i problemima koje suvremeni čovjek u nedostatku vremena pokušava rješavati konzumacijom lijekova koji zatomljuju simptome, ali ne rješavaju problem. Stoga autor sugerira svojim čitateljima da lijekove zamijene čitanjem filozofskih djela i interpretacijom filozofskih tekstova uz pomoć filozofskog savjetnika. 
lje pripremio i s njima se adekvatno suočio. ${ }^{29}$ Misli Seneke koje se revitaliziraju posljednjih godina slične su Sokratovu polazištu prema kojemu je filozofija briga o duši koja nosi kreposti iz kojih se može popločati put k boljem životu. Ukoliko je filozofija praktična djelatnost koja ima za cilj voditi sretnijemu i boljemu životu, te pomoći oslobođenju od briga i razarajućih strasti, zadatak čovjeka je da pomoću nje, upravo filozofirajući, pokuša pronaći sebe, odnosno istraži svoje mogućnosti. ${ }^{30}$

Filozofija, drugim riječima, ima važnu tješiteljsku i terapeutsku ulogu. Aktualiziranje takve (praktične) filozofije svakako može biti od pomoći suvremenomu čovjeku-radniku, koji je izložen neočekivanim preokretima i preopterećenostima, u jednakoj mjeri kao nezaposlenosti i monotoniji, ali koji nije odustao od vlastite sreće. Filozofija tako može pomoći radniku da se lakše nosi sa životnim situacijama, da zauzme ispravan stav spram onog što se događa i da ima što realnija očekivanja o onom što bi se moglo dogoditi. Prihvatiti događaje, posebice one bolne, emocionalno teške ili neočekivane nije nimalo lagana zadaća, ali je upravo prihvaćanje realnog stanja jedan od imperativa, kako filozofije, tako i dokolice. U protivnom jaz između želja i stvarnosti postaje samo dublji, a tjeskobe mučnije.

Onaj tko se odupire ili barem sumnjiči nametnute društvene obrasce, rad kao najveću vrijednost, rad radi rada, funkcionalnost i korisnost kao apsolutne vrijednosti, može se obratiti filozofiji za pomoć. Talijanski filozof Abbagnano ističe da je »promjena nâvika već odmor «, 31 ali prava pomoć čovjeku da osmisli dokolicu i u dokolici samoj vidi njenu svrhu mogao bi biti novi zadatak, ali i novi prostor filozofije u društvu koje bi imalo manje problema s radom da ima kvalitetniju dokolicu jer »jedino se u pravoj dokolici otvaraju vrata u slobodi iz zatvorena područja pritajena straha u kojem oštroumni promatrač vidi osobinu svijeta rada, u kojem su rad i nezaposlenost dva pola bezizlaznosti postojanja «.32

Filozofija može pomoći čovjeku da se svjesno i odgovorno suoči s realnim stanjem u kojem se nalazi i da prije svega prihvati stvarnost takvu kakva jest. Onaj tko otkrije da je nezadovoljan i nesretan, kada se odvaži na dublje filozofsko suočavanje s takvim stanjem, nužno mora u početku osjećati frustracije, strahove i bolove. To su prijelomna stanja na putu k novomu čovjeku, koraci na putu postajanja čovjekom kakvim treba biti. Upravo filozofija može pomoći u tom kako se s takvim stanjima nositi, kako ih analizirati i kako ih naučiti podnositi. To je filozofski put k sreći, preko mudre i promišljene reakcije na poteškoće na koje se nailazi u radnoj svakodnevnici, shvaćajući da ono što trenutačno zadovoljava nije

29 Usp. Giovanni Reale, La filosofia di Seneca come terapia dei mali dell'anima, str. 97-155.

30 Isto je razmišljao i Platon poučavajući da je filozofija duhovna medicina pomoću koje se može postići umjerenost. Cilj brige o duši (filozofije) je usrećiti čovjeka i osmisliti dobar život pomoću rasprava i dijaloga odustajući ili odričući se izvanjskih stvari, koje su naposljetku samo izvori novih briga, problema i nesreća. Zadatak filozofije je pomoći čovjeku da vrednuje stvari na ispravan način, da uredno vodi svoj život, upravlja svojim (re)akcijama i prizna svoje nedostatke.

31 Nicola Abbagnano, La saggezza della vita, str. 113.

32 Joseph Pieper, Pohvala dokolici, str. 68. 
nužno prava sreća, kao što ni ono što izaziva patnju i nezadovoljstvo nije uvijek nepopravljivo zlo.

\section{Zaključak}

Čovjek u svom postojanju i djelovanju osjeća nemir koji ga tjera da preispituje stvarnost, dovodi u sumnju vlastite postupke, propituje svoj položaj u svijetu i ključne koncepte koji ga oblikuju. Taj nemir zapravo je spiritus movens filozofske prakse, unutarnja snaga koja čovjeka pokreće da traga za dobrim i sretnim životom.

Možemo reći da upravo filozofija predstavlja neumorno traganje za dobrim životom, za mudrošću bez koje život postaje težak, surov i monoton. Zauzeti ispravan stav prema životu, vremenu, uspjehu, radu i odmoru, ohrabriti se za promjene, za osobni napredak i za nova pitanja može biti i jest zadatak filozofije spram bilo kojeg čovjeka, posebice prezaposlenog i premorenog radnika. Filozofija bi mogla pomoći čovjeku odgajajući ga za dokolicu, ono stanje uma u kojem je osoba otvorena za nova pitanja, perspektive i pristupe životu. Filozofija može čovjeka naučiti razmišljati o problemima koje susreće, a da ga nužno ne dovede do rješenja; može ga staviti na put, a da ga nužno ne dovede do cilja, jer filozofija, prije svega, ima zadatak razotkriti lažne vrijednosti i iluzornu sreću te pokrenuti i pripremiti čovjeka na put koji ga može odvesti u smisleniji život. Prakticirajući filozofiju čovjek može otkriti nove kriterije vrednovanja života, rada i okolnosti u kojima se nalazi. Može naučiti vagati vlastite izbore i donositi ispravne odluke, u slobodi preuzeti inicijativu, poštovati uravnoteženost, težiti punini svojeg života te uskladiti želje sa zbiljom koja ga okružuje.

Filozofska baština svojom raznolikošću pristupa životu ukazuje na to da je život dostojan radosti, ali i suza, umora i odmora, nemira i unutarnjeg mira. Stoga, filozofiranje i dijalogiziranje s filozofima može čovjeku pomoći da vidi svoje granice, ali i da se usudi misliti iznad njih. Filozofija čovjeka može potaknuti da se izolira od svakodnevnih briga, da se osami, da mu se razbistri slika onoga što može biti i da dobije snagu da to i postane, kao i da se odupre onomu što mu škodi. Dakle, filozofija ga može usmjeriti na put na kojem će naučiti uvesti red u misli i mir u odnose s drugima.

Zadatak filozofije jest pomoći čovjeku da razvije svoju osobnost, iskoristi svoju slobodu i vrijeme, a time i vlastiti život na najbolji mogući način. Zbog toga se mogu odbaciti optužbe da je populariziranje filozofije, odnosno apliciranje filozofije u svakodnevnom životu njezina zlouporaba, tj. njezin kraj. Ipak nedopustivo je da se svaka zbunjujuća, nestrukturirana i neutemeljena misao zove filozofskom. Isto tako, neispravno je svakog gosta u filozofskom kafiću ili slučajnog polaznika filozofskog savjetovanja, kao i preopterećenog ili nezaposlenog čovjeka koji ubija vrijeme čitajući filozofska djela, nazivati filozofom. Međutim, ispravno prakticiranje filozofije pomaže čovjeku radniku i filozofu da u punini svojeg života i u zadovoljstvu življenja, u kojem je rad tek jedna od mnogih sastavnica, pronađe sreću i slobodu za kojima tako neumorno teži. 
Philosophy as Giver of Solace - Philosophical Counselling in the Service of Workers

Ana Jeličić*, Antun Japundžić**

Summary

Unemployment is considered by many to be the biggest problem that we face today. This weighty issue obscures the state in which the overworked individual finds himself. Extreme busyness stands in opposition to another's lack of occupation and evokes much dissatisfaction, fear, fatigue, feelings of purposelessness and hopelessness. Unable to decide for himself what he will do in life and what will occupy his time, man senses that he is losing both, that they are slipping away as is also that particularity which identifies him with his work capabilities. Lately, a trend has been noted in the world which distinguishes man at his workplace as a worker and in his leisure time as a philosopher. During the week the philosopher is an overworked employee and on weekends a toiler. In other words, philosophers are abandoning their exclusiveness and academic circles in order to solve daily problems. Can philosophy provide therapy (L. Marinoff, G. Reale or Seneca), solace and consolation (A. de Botton), counselling and an opportunity to begin anew (G.B. Achenbach) for the worker desirous of rest, leisure, creativity, contemplation and relaxation (J. Pieper) by teaching him to ask questions about life and by making him a protagonist of his own life? Or is applied philosophy merely more marketing story.

Key words: work, worker, overwork, leisure, philosophy, philosophical counselling

* Ana Jeličić, Ph.D., The University Department of Forensic Sciences, University of Split. Scientific Center of Excellence for Integrative Bioethics, University of Zagreb. E-mail: anjelici08@ gmail.com

** Antun Japundžić, Ph.D., The Catholic Faculty of Theology in Đakovo. The Josip Juraj Strossmayer University of Osijek, Croatia. E-mail: antun.japundzic@gmail.com 